\title{
Faktor-Faktor Infrastruktur Teknologi Informasi Corporate di Kota Palembang
}

\author{
Darius Antoni, S.Kom., M.M., P.hD. \\ Program Studi Teknik Informatika \\ Fakultas Ilkom, Universitas Bina Darma \\ Jl. Jend. A. Yani No. 3 Palembang 30264 Indonesia \\ Darius.antoni@binadarma.ac.id
}

\author{
Fatoni, M.M., M.Kom. \\ Program Studi Teknik Informatika \\ Fakultas Ilkom, Universitas Bina Darma \\ Jl. Jend. A. Yani No. 3 Palembang 30264 Indonesia \\ fatoni@binadarma.ac.id
}

\begin{abstract}
Abstrak- Teknologi informasi (TI) dapat diadopsi sebagai kemampuan organisasi untuk meningkatkan kinerja organisasi dalam rangka memenuhi peraturan pemerintah, meningkatkan profitabilitas, dan meningkatkan posisi kompetitif di pasar. Tujuan dari penelitian ini untuk mengembangkan model kemampuan IT berdasarkan dari kualitas infrastruktur TI, yang digunakan organisasi untuk mendukung proses bisnis. Model ini dikembangkan berdasarkan pandangan berbasis infrastruktur TI sebagai landasan teoritis dan literatur yang berhubungan dengan kinerja organisasi. Validitas model ini akan diuji menggunakan model persamaan struktural berdasarkan data yang dikumpulkan dari organisasi di kota Palembang. Data yang dikumpulkan akan di analisis dengan menggunakan perangkat lunak SPSS dan AMOS. Hasil penelitian ini diharapkan dapat mengembangkan kemampuan infrastruktur TI untuk meningkatkan kemampuan dari suatu organisasi yang digunakan untuk mengembangkan proses bisnis digitalisasi untuk berkompetisi di pasar global. Hasil penelitian diharapkan juga menghasilkan sebuah model baru mengenai infrastruktur IT yang merupakan kontribusi asli untuk literatur sistem informasi khususnya hubungan antara infrastruktur TI yang dihubungkan dengan kinerja organisasi.
\end{abstract}

Kata kunci- IT capability, Organizational performance, infrastruktur TI, IT Resources manusia, sistem informasi.

\section{PENDAHULUAN}

Organisasi semakin khawatir tentang kinerja lingkungan dari operasi mereka dalam lingkungan yang kompetitif saat ini. Hal ini karena secara efektif meningkatkan kinerja organisasi dapat membantu organisasi untuk memenuhi peraturan dan standar kepatuhan, meningkatkan profitabilitas organisasi, memberikan organisasi dengan peluang bisnis, dan meningkatkan posisi kompetitif organisasi di pasar Akibatnya, organisasi telah menerapkan kebijakan dan strategi khusus untuk meningkatkan kinerja organisasi. Ada banyak pendekatan dan teknik termasuk adopsi teknologi informasi dan Komunikasi (TIK) bahwa organisasi dapat digunakan untuk meningkatkan kinerja organisasi (Tippins and Sohi, 2003, Mingay, 2007, Speshock, 2010, Xiaoxia et al., 2012). Mingay (2007), misalnya, menunjukkan bahwa organisasi dapat menggunakan TI untuk secara signifikan mengurangi karbon dioksida dari operasi bisnis mereka. Sayeed and Gill (2008) menyatakan bahwa organisasi dapat meningkatkan kinerja mereka melalui efektif mengelola sumber daya TI mereka. (Dao et al., 2011) menyatakan bahwa organisasi dapat mengurangi konsumsi energi mereka melalui penggunaan dokumen digital dan mengotomatisasi kegiatan usaha yang berbeda. Studi ini menunjukkan bahwa IT dikembangkan dan digunakan sebagai kemampuan dalam suatu organisasi untuk meningkatkan kinerja mereka (Molla, 2008, Molla et al., 2011).

Kemampuan IT adalah kemampuan suatu organisasi secara efektif dan efisien memanfaatkan sumber daya TI untuk meningkatkan kinerja organisasi (Boudreau et al., 2008). Hal ini dapat lihat dari perspektif yang berbeda termasuk infrastruktur TI, sumber daya manusia (SDM) TI, dan manajemen TI (Kettinger et al., 1994, Bharadwaj, 2000, Lee et al., 1995b). (Kettinger et al., 1994), misalnya, berpendapat bahwa kemampuan IT adalah kemampuan suatu organisasi dalam menggunakan infrastruktur TI untuk mencapai keunggulan kompetitif. Lee et al. (1995a) menyatakan bahwa kemampuan IT adalah kemampuan organisasi untuk secara efektif mengelola operasi organisasi mereka melalui penggunaan yang efektif dari SDM TI dalam suatu organisasi. Bharadwaj (2000) menunjukkan bahwa kemampuan IT adalah kemampuan organisasi yang diciptakan oleh interaksi antara infrastruktur TI, SDM TI, dan TI aset tidak berwujud dalam sebuah organisasi untuk meningkatkan kinerja organisasi. Tippins and Sohi (2003) berpendapat bahwa kemampuan IT adalah kemampuan organisasi dalam menggunakan sumber daya TI untuk meningkatkan kinerjanya. (Jiao et al., 2008) menyatakan bahwa kemampuan IT ditentukan oleh infrastruktur TI, SDM TI dan manajemen TI dapat digunakan untuk meningkatkan kinerja organisasi. Dalam research ini, kemampuan TI disebut sebagai 
kemampuan suatu organisasi dalam memanfaatkan infrastrutur TI untuk meningkatkan kinerja organisasi.

Disamping itu, berdasarkan penelitian yang dilakukan oleh Kementerian Komunikasi dan Informatika Indonesia tahun 2011(Ministry of Telecommunication and Informatics, 2011) menunjukan bahwa sebagian besar pelaku bisnis 92\% telah menggunakan TIK sebagai sarana penunjang proses bisnis mereka. Tingkat penggunaan TIK di organisasi-organisasi tersebut dipengaruhi oleh besarnya skala usaha. Ini bearti bahwa semakin besar skala usaha bisnisnya (jumlah Pekerja) semakin besar pula ketergantungan terhadap penggunaan TIK dalam mejalankan bisnis. Jumlah perusahaan mikro yang telah menggunakan komputer sebanyak $71,84 \%$. Perusahaan kecil menengah yang telah menggunakan komputer nilainya lebih banyak dari perusahaan mikro yaitu 92,74 dan 97. Sedangkan perusahaan skala besar yang telah menggunakan komputer sebesar $100 \%$.

Dengan memperhatikan hal-hal diatas, penelitian ini mencoba untuk memperoleh data empirik yang cukup lengkap dan dapat dipercaya untuk mengambarkan tentang keadaan infrastruktur TI yang terkait dalam pengelolahan sistem informasi corporate (SIC) berbasis TIK terhadap kinerja organisasi yang dampaknya untuk meningkatkan pelayanan informasi terhadap stakeholder mereka. Hal ini dikarenakan bahwa dinamika kebutuhan akan TI dalam pengelolahan dan mengkontrol bisnis sangat penting bagi keperluan berbagai pelayanan dan pengambilan keputusan.

Tujuan penelitian ini yaitu untuk mendapatkan model kemampuan infrastruktur TI dalam pengembangan dan pengelolahan SIC pada organisasi-organisasi di kota Palembang. Model ini selanjutnya akan divalidasi dan dites berdasarkan data survei yang diambil dari perusahaanperusahaan yang ada di Kota Palembang dengan menggunakan Structural Equation Modelling (SEM). Penelitian ini menunjukan bahwa implementasi network system, penyediaan multiflatform user interface, tersedianya informasi dan data di semua unit di dalam organisasi, implementasi virtual server, database, dan desktop, implementasi thin clients, implementasi cloud computing, dan implementasi radio frequency identification adalah faktor-faktor penting di intrastruktur TI di dalam implementasi SIC di kota Palembang.

Struktur jurnal penelitian ini dimulai dari metode penelitian dilanjutkan dengan pembahasan tentang infrastruktur TI, hasil dan pembahasan dan yang terakhir adalah kesimpulan.

\section{METODE PENELITIAN}

Data untuk penelitian ini dikumpulkan dengan menggunkan metode survei. Survei ini melibatkan distribusi kuesioner survei kepada responden diidentifikasi. Responden dipilih dengan menggunakan pendekatan clustering didasarkan pada jenis perusahaan. Kriteria Samping adalah untuk menargetkan Direktur atau orang yang mempunyai keputusan dalam penggunaan TI sperti manajer TI. Dengan demikian, kami percaya bahwa manajer TI atau setara dari divisi IT. Maka, manajer TI adalah target utama dalam meningkatkan kinerja organisasi (Bowen et al., 2001, Zhu et al., 2005). Software SPSS digunakan untuk mendefinisikan nilai-nilai yang dapat diterima dan label untuk masing-masing variabel. Selanjutnya, data akan disimpan dan disaring menggunakan SPSS 21.0 untuk mengatasi missing data value, normalitas, outlier, dan common method bias. Tujuannya adalah untuk menghindari kegagalan estimasi model dan mendapatkan nilai yang optimal (Kline, 2010). Setelah data screening, data akan tersisa dianalisis lebih lanjut dengan menggunakan AMOS versi 19.0.

Prosedur penelitian ini disusun menjadi empat tahap, yaitu: tahap literature analisis, pre-test, Pilot Studi dan Survei. (1) Tahap literature analisis. Analisis literatur digunakan unuk mengembangkan kuesioner survei penelitian dalam menentukan penggunaan skala pengukuran. Ada beberapa skala pengukuran yang digunakan dalam penelitian sebelumnya. Mereka skala pengukuran yang diadopsi berdasarkan konteks dan latar belakang penelitian yang berbeda. Maka, ada kebutuhan untuk menganalisis, memodifikasi dan meninjau instrumen diperoleh bentuk studi yang ada, yang sesuai dengan lingkungan bisnis dari organisasi

Pemilihan dan teknik statistik yang akurat untuk memilih yang sesuai dan cocok skala waktu juga diperlukan, setelah analisis yang komprehensif dari literatur, penelitian ini memilih 5 poin skala Likert. Lima poin jenis likert skala dipilih karena memiliki manfaat dalam memberikan hasil yang lebih akurat dan konsisten untuk analisis multivariat dari rentang yang lebih kecil, seperti skala Likert lima poin (Hair et al 2010).

Tahapan kedua adalah Pre-test, diperlukan untuk memperbaiki instrumen survei penelitian. Hal ini digunakan untuk memvalidasi validitas isi instrumen survei (Hair et al 2010). Validitas isi adalah tentang kegiatan yang melibatkan berbagai aspek atau dimensi konstruk untuk menyelidiki sejauh mana item pengukuran yang digunakan dalam penelitian (hair et al 2010).

Proses ini dapat diidentifikasi oleh penilaian terhadap kata-kata, comprehesibility, konsistensi interpertation, sequencing logis, dan kesan keseluruhan dari tampilan dan nuansa dari survei. Para ahli yang dilibatkan untuk melakukan pre-test instrumen survei. Mereka adalah akademis dan profesional yang memiliki pengetahuan dalam 
penggunaan IT dalam organisasi. Mereka diminta untuk memeriksa setiap pertanyaan dari survei dengan hati-hati dan memberikan beberapa saran dan komentar pada relevansi konten, kata-kata, dan struktur instrumen survei. Oleh karena itu, saran dari para ahli yang digunakan untuk memperbaiki dan memodifikasi instrumen survei.

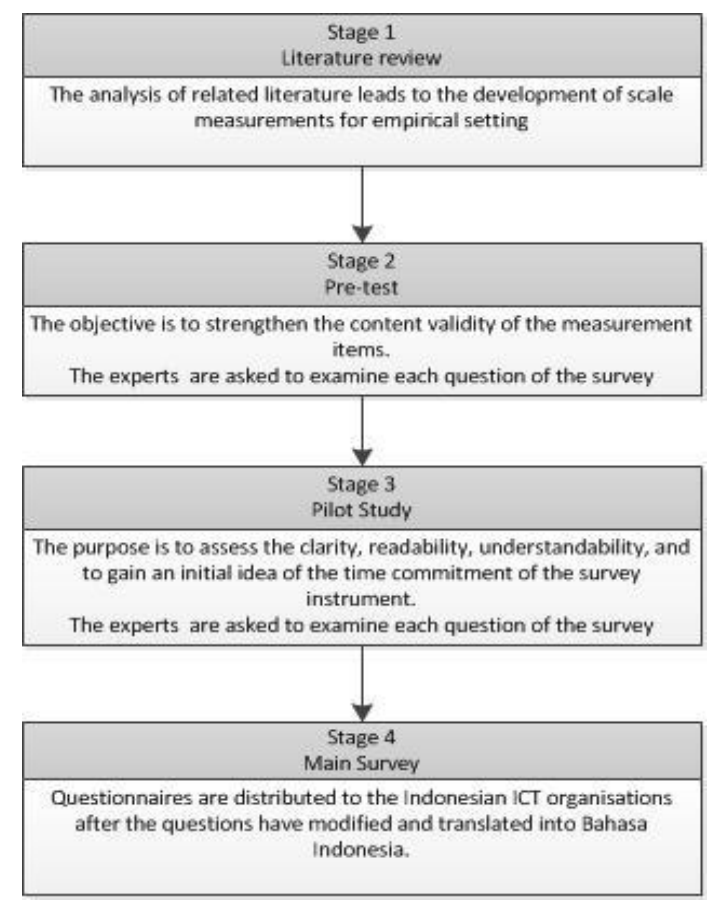

Gambar 1. Tahapan Penelitian

Setelah mengumpulkan komentar dan saran dari para ahli untuk meningkatkan instrumen survei, versi terbaru dari kuesioner survei ini kemudian dikirim ke 20 puluh atau lebih responden untuk pilot studi. Kegiatan Inisiatif ini dilakukan untuk menilai kejelasan, mudah dibaca, dimengerti dan untuk mendapatkan gambaran awal dari instrumen survei. Ada revisi minor dilakukan berdasarkan pilot studi. Ini mencakup modifikasi beberapa instrumen survei. Oleh karena itu, setelah semua tapapan dilalui maka tahap terakhir adalah survei ke semua respoden.

\section{INFRASTRUKTUR TEKNOLOGI INFORMASI}

Teknologi Informasi (TI) infrastruktur adalah dasar bagi organisasi untuk meningkatkan performa mereka. Dalam lingkungan bisnis yang dinamis, perusahaan adalah salah satu contoh organisasi yang membutuhkan proses digitalisasi untuk meningkatkan produk dan / atau pelayanan jasa untuk melayani stakehoder internal dan eksternal. Berdasarkan teori Resource Based View (RBV), infrastruktur TI dalam penelitian ini terdiri dari flexibiity, Serviceability, greenness ability. Flexibility adalah kemampuan dari infrastruktur TI untuk beradaptasi dengan kebutuhan organisasi
(Duncan, 1995). Kemampuan ini terdiri dari modularisasi sistem informasi, standarisasi format laporan dan informasi, implementasi simple administrasi, adopsi network systems, dan data privacy dan security. Service ability adalah kemampuan yang dimiliki oleh infrastruktur TI dalam memberikan layanan lintas flatform, lokasi dan waktu (Weill and Vitale, 2002, Broadbent and Weill, 1997). Sedangkan greenness ability adalah kemampuan yang dimiliki oleh infrastruktur TI untuk meningkatkan efficiensi business prosess. Kemampuan ini dapat ditingkatkan dengan mengimplementasi virtualisasi server, storage virtualisasi, virtualisasi desktop dan thin client computing, cloud computing, dan adopsi radio frequency identification (RFID) (Miller and Pegah, 2007, Kovar, 2008). Virtualisasi mengacu pada infrastruktur TI yang memiliki kemampuan untuk berbagi layanan dengan teknologi platform yang berbeda termasuk platform perangkat keras, platform perangkat lunak dasar, teknologi komunikasi dan middleware. Hal ini juga digunakan untuk mendukung kesamaan antara aplikasi yang berbeda dan menggunakan serta memfasilitasi berbagi informasi menemukan dan di luar organisasi, infrastruktur integrasi lintasfungsional dan mengurangi biaya operasi bisnis.

Jadi dapat disimpulkan bahwa, infrastruktur TI di organisasi memberikan standarisasi informasi dan data yang dapat diakses oleh seluruh mitra bisnis termasuk pelanggan, pemasok dan pemerintah.

\section{PEMBAHASAN}

A. Profil Responden

Responden pada penelitian ini terbatas pada Direktur dan IT manager atau pihak pengambil keputusan di perusahaan-perusahaan kota Palembang. Adapun jumlah responden yang berhasil didapat sebanyak 250 responden yang terdiri dari industri manufaktur, perkebunan, perdagangan dan jasa. Tabel 1. menampilkan jumlah tipe perusahaan yang menjadi responden pada penelitian ini. Seperti yang ditampilkan pada tabel tersebut, industri perkebunan sebanyak $10 \%$, manufaktur 5\%, Perdagangan $40 \%$ dan jasa lainnya sebanyak $45 \%$.

Tabel 1. Tipe perusahaan

\begin{tabular}{|c|l|r|r|}
\hline No & Organisation Types & Freq & \multicolumn{1}{c|}{$\%$} \\
\hline 1 & Manufaktur & 13 & $5 \%$ \\
\hline 2 & Perkebunan & 25 & $10 \%$ \\
\hline 3 & Perdagangan & 100 & $40 \%$ \\
\hline 4 & Jasa & 100 & $40 \%$ \\
\hline 5 & Lainnya & 12 & $5 \%$ \\
\hline \multicolumn{2}{|c|}{ Total } & 250 & $100 \%$ \\
\hline
\end{tabular}

Di tabel 2 menunjukan bahwa responden berdasarkan jenis posisi responden di perusahaan. 
Ada 22 responden menduduki jabatan sebagai Direktur di perusahaan atau organisasi, manager sebanyak 104 responden, supervisor sebanyak 101 responden dan sisanya sebanyak 23 mempunyai posisi sebagai staff atau pegawai.

Tabel 2. Posisi Responden

\begin{tabular}{|c|l|r|r|}
\hline No & Positions & Freq & \% \\
\hline 1 & Direktur & 22 & 8,8 \\
\hline 2 & Manager & 104 & 41,6 \\
\hline 3 & Supervisor & 101 & 40,4 \\
\hline 4 & others & 23 & 9,2 \\
\hline Jumlah & 250 & 100 \\
\hline
\end{tabular}

Tabel 3. menunjukkan bahwa pendidikan responden dalam organisasi. Para responden yang telah menyelesaikan gelar sarjana mereka menyumbang 70,8 persen dari responden. Responden yang memiliki gelar master sebesar 18,8 persen dari total responden dan 7,3 persen mereka memiliki ijazah atau gelar diploma tiga. Ini diikuti oleh responden yang memiliki pendidikan SMA dengan 3,1 persen dari total responden.

Tabel 3. Pendidikan Responden

\begin{tabular}{|c|l|r|r|}
\hline No & Experiences & Freq & \% \\
\hline 1 & SMA atau Sederajat & 12 & 4,8 \\
\hline 2 & Diploma & 28 & 11,2 \\
\hline 3 & Sarjana & 172 & 68,8 \\
\hline 4 & Master & 38 & 15,2 \\
\hline 5 & Doktor & 0 & 0 \\
\hline Jumlah & 250 & 100 \\
\hline
\end{tabular}

Jika dilihat dari tingkat kemahiran dalam penggunaan IT, sebagian besar responden memiliki tingkat tinggi kemahiran dalam penggunaan IT dengan 50 persen dari mereka dan 45,6 persen telah rata-rata kemampuan dalam penggunaan IT diikuti oleh responden keterampilan rendah menggunakan TI dengan 4,4 persen dari responden.

Table 4. Tingkat Kemampuan IT

\begin{tabular}{|l|l|r|r|}
\hline No & Experiences & Freq & \% \\
\hline 1 & Low & 17 & 6,8 \\
\hline 2 & Average & 175 & 70 \\
\hline 3 & High & 58 & 23,2 \\
\hline Jumlah & 250 & 100 \\
\hline
\end{tabular}

\section{B. Uji Missing Data Value}

Data penelitian ini dikumpulkan di Kota Palembang menggunakan kuesioner berbasis kertas dan survei online (lihat lampiran untuk kuesioner survei). Kuesioner dibagikan kepada sekitar 510 organisasi atau perusahan di Palembang. Setelah kuisioner awal keluar (dipertama Maret 2016), untuk memastikan responden menjawab semua pertanyaan yang ada di kuisioner, sejumlah upaya yang dilakukan baik secara pribadi dan melalui telepon hingga akhir Mei 2016. Setelah tiga bulan,
279 tanggapan diterima. Pemeriksaan awal dari 279, teridentifikasi 24 kasus missing value dengan data terlalu banyak yang hilang atau kosong dan data ini dihapus dikeluarkan untuk analisis lebih lanjut. Ini meninggalkan 255 kasus untuk analisa lebih lanjut. Uji Missing data value ini mengacu pada situasi di mana nilai-nilai yang berlaku pada satu atau lebih variabel yang tidak tersedia untuk analisis (Hair 2010). Semua data yang dihapus dalam penelitian ini adalah karena responden tidak menjawab seluruh atau lebih dari $50 \%$ pertanyaan yang ada di kuisioner. Hal ini membutuhkan penilaian lebih lanjut dari tingkat dan dampak dari data yang hilang. Keseluruhan data yang tidak dijawab akan dinilai dengan menghitung jumlah kasus dengan data untuk setiap variabel dan jumlah variabel yang hilang dalam kasus tertentu. Anlisis menunjukkan bahwa ada 9 data yang hilang dalam kumpulan data, termasuk data nilai non-metrik. Berdasarkan analisis, data yang hilang kurang dari $10 \%$ muncul secara acak dan kemudian data yang hilang secara umum dapat diabaikan(Kaplan, 2009, Hair, 2010). Hal ini karena data tidak mempengaruhi pengamatan keseluruhan temuan penelitian (Kaplan 2009; Hair et al 2010). Oleh karena itu, data yang hilang dapat digantikan oleh nilai yang sesuai (Kaplan, 2009).

Setelah mengidentifikasi Missing Data Value, langkah berikutnya adalah untuk menggantikan data yang hilang menggunakan software SPSS. Menggantikan data yang hilang dengan menggunakan teknik Ekspektasi-Maksimalisasi (EM) diterima secara luas untuk menangani data yang hilang. Ini adalah teknik yang cocok bila data yang hilang muncul secara acak. Oleh karena itu dalam penelitian ini, nilai-nilai yang hilang akan diganti dengan nilai yang sesuai yang dihasilkan dengan teknik EM di software SPSS.

\section{Uji Outlier}

Outlier mengacu pada sebuah kasus atau observasi pada sebuah nilai variabel atau kombinasi variabel yang secara substansial berbeda dari orang-orang dalam kasus lain atau pengamatan (Tabachnick and Fidell, 2001, Hair, 2010). Outliers dapat didefinisikan tidak mewakili populasi. Mereka dapat mendistorsi uji statistik, dan dengan demikian bekerja bertentangan dengan tujuan dari studi penelitian. Outliers dapat diperiksa dari sudut pandang, bivariat, univariat dan multivariat. Penelitian ini melakukan uji multivariat untuk outlier menggunakan tool SEM. Ada beberapa metode umum untuk mengidentifikasi outlier multivariat dalam penelitian. Perhitungan Squred Mahalanobis Distance (D2) adalah salah satu metode yang populer untuk mendeteksi outlier. Mengukur jarak dari kasus dari pusat massa (multidimensi rata-rata) dari distribusi, mengingat kovarians (multidimensi varians) distribusi. Dengan menggunakan ukuran statistik ini, data survei 
diperiksa untuk mendeteksi outlier yang serius mempengaruhi analisis data. Menurut Hair et al. (2010), outlier dapat diidentifikasi dengan nilai / df D2 melebihi tiga atau empat sampel besar. Oleh karena itu, dalam penelitian ini (279 sampel), ada 5 kasus terdeteksi sebagai outlier serius yang memiliki D2 nilai / df yang sama dengan atau melebihi nilai tiga. Outlier ini dihapus dari frase analisis (Shumacker \& Lomax, 2004).

Jadi, di dalam penelitian ini teridentifikasi 6 kasus outlier dan menghapus mereka dari analisis lebih lanjut. Oleh karena itu, hanya 250 kasus yang tersisa digunakan dalam semua analisis selanjutnya yang akan dilakukan sebagai bagian dari studi ini.

\section{Uji Normalitas}

Uji normalitas diperlukan untuk $m$ distribusi dan karakteristik statistik untuk variabel individu yang mendekati distribusi normal. Seperti yang disarankan oleh Hair (2010), normalitas dapat diperiksa berdasarkan skewness dan kurtosis nilai. Skewness menggambarkan keseimbangan simetris distribusi. Itu baik bisa menjadi negatif (distribusi yang cenderung dan bergeser ke kanan) atau positif (distribusi yang cenderung dan bergeser ke kiri). Kurtosis mengacu pada "peakiness" atau ketinggian distribusi. Sebuah kurtosis positif menunjukkan puncak yang lebih tinggi dari distribusi normal. Sebuah kurtosis negatif menunjukkan bahwa distribusi adalah datar dari distribusi normal. Berangkat dari normalitas dalam hal kurtosis dan skewness menunjukkan pelanggaran asumsi normalitas.

The kurtosis dan skewness hasil dari survei akan diinput kedalam SPSS dinilai menggunakan AMOS 21. Hasil statistik dari skewness dan kurtosis, nilai statistik mereka dibagi dengan standard error masing-masing sehingga mendapatkan rasio kritis skewness (ZSkewness) dan kurtosis (ZKurtosis ) untuk 3 metrik variabel. Dari hasil tersebut menunjukan penyimpangan dari normalitas dalam tes normalitas keseluruhan menerapkan ketat 7 dan -7 rasio kritis kurtosis. Menurut ukuran lebih ringan dari kurtosis, tidak satupun dari tiga variabel menunjukkan masalah (Kline, 2010).

\section{E. Uji Common Metode Bias}

Uji Common Metode Bias atau commom method variance adalah tentang varian yang mungkin terjadi sebagai hasil dari metode pengukuran, bukan karena konstruksi yang mengukur mewakili. Data yang dikumpulkan dari responden yang sama untuk predicator dan criterion variabel menggunakan metode tunggal dan / atau pada satu titik waktu yang sama mungkin memiliki bagian dari varian yang item pengukuran berbagi kesamaan. Hal ini dikarena lebih mementingkan metode pengumpulan data daripada hubungan hipotesis dalam model penelitian yang diusulkan. Metode Bias, jika ada, menyebabkan kesalahan pengukuran yang negatif mempengaruhi keabsahan kesimpulan yang ditarik.

Hasil perhitungan menunjukkan bahwa hasil analisis faktor menggunakan analisis principal unrotated. Hasilnya mengungkapkan kehadiran sebanyak 14 faktor dengan nilai Eigen lebih besar dari 1, perhitungan untuk sekitar 75 persen dari varians dalam tindakan. Namun, faktor pertama dan terbesar menjelaskan hanya 33 persen dari varians dalam ukuran, yang berarti bahwa nilai kurang dari 50 persen yang diperlukan untuk menunjukkan Common Method Bias. Oleh karena itu, salah satu faktor melakukan faktor tunggal emerge untuk mewakili varians antara semua item pengukuran.

F. Uji Validitas dan Reliabilitas Instrumen

Responden dalam penelitian ini adalah perusahaan yang berlokasi di kota Palembang berjumlah 250 responden, dengan perincian 100 Perdagangan, 100 Jasa, 13 Manufaktur, dan 25 Perkebunan. Uji reliabilitas instrumen dilakukan dengan melihat koefisien $\alpha$ Cronbach, dan jika $\alpha>$ 0.6 maka instrumen penelitian dikatakan reliable. Ringkasan hasil uji validitas dan reliabilitas instrumen penelitian dapat dilihat pada Tabel 5.

Table 5. Uji Reliabilitas dan Validitas

\begin{tabular}{|l|c|c|c|}
\hline Constructs & $\begin{array}{c}\text { Number } \\
\text { of items }\end{array}$ & $\begin{array}{c}\text { Korelasi item- } \\
\text { total }\end{array}$ & $\begin{array}{c}\text { Cronbach's } \\
\text { alpha }\end{array}$ \\
\hline Infrastruktur & 14 & $\begin{array}{c}0.629 \mathrm{~s} / \mathrm{d} \\
0.822\end{array}$ & 0.835 \\
TI & & 0.825 \\
\hline
\end{tabular}

\section{HASIL ANALISIS DATA}

Hasil Confirmatory Factor Analysis (CFA) menggunkan AMOS terhadap model dasar penelitian adalah sebagaimana ditunjukkan dalam gambar model infrastruktur TI Sistem Informasi Corporate (SIC) yang terdiri dari flexibility, service ability, greenness ability. Hasil yang diharapkan dari pengolahan AMOS ini adalah berupa kemampuan infrastruktur TI yang penting dalam menunjang SIC.

Hasil uji konstruk Infrastruktur TI pertama disajikan pada Gambar 2. Gambar tersebut menunjukan bahwa ada 5 item (ITF01, ITF02, ITF03, ITS05 dan ITS08) dari infrastruktur TI dihapus dikarenakan nilai faktor loadingnya kurang dari 4 (Ferdinand, 2002). Hasil pengukuran faktor setelah penghapusan menunjukan tidak ada faktor loading dari setiap faktor kurang dari 0.4 seperti yang ditampilkan pada gambar 2. Selain itu, hasil uji konstruk Infrastruktur TI disajikan berdasarkan goodness of fit indices pada tabel 6. Berikut dengan disajikan kriteria model serta nilai kritisnya yang memiliki kesesuaian data. 
Berdasarkan fakta empiris seperti pada Tabel 6 dan gambar 2, dapat dikatakan bahwa konstruk infrastruktur TI memiliki faktor-faktor penting yaitu implementasi Network Systems, interface multiplatforms, Database management systems, Virtual server, virtual database, Virtual Desktop, Thin Client computing, Cloud Computing, dan Radio Frequency Identifications(RFID). Jadi, dapat disimpulkan bahwa untuk mendukung bisnis proses dalam suatu perusahaan dibutuhkan suatu Infrastruktur TI seperti yang disebutkan diatas.

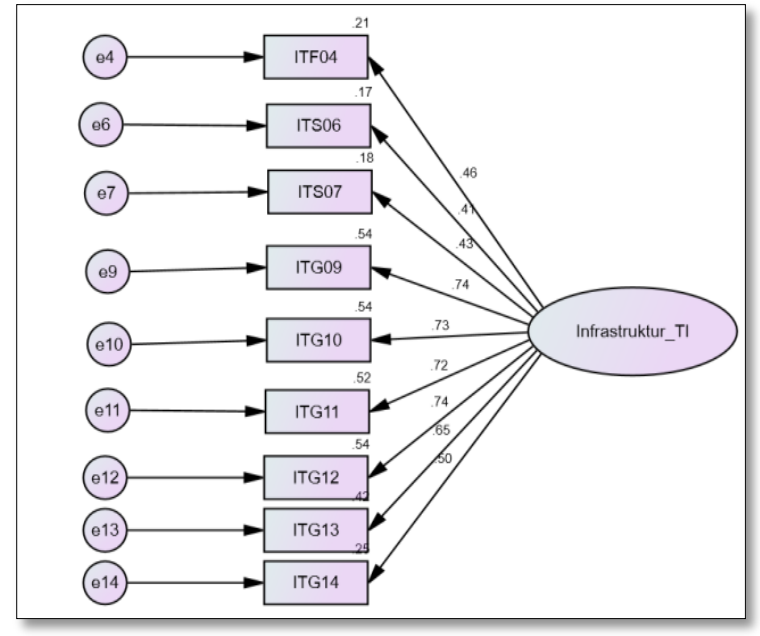

Gambar 2. Pengukuran ulang Faktor Infrastruktur TI

Tabel 6. Evaluasi kriteria Goodness of Fit Indices subdimensi Infrastruktur TI

\begin{tabular}{|c|c|c|c|}
\hline $\begin{array}{c}\text { Goodnes } \\
\text { s of fit } \\
\text { index }\end{array}$ & $\begin{array}{c}\text { Cut-off } \\
\text { Value }\end{array}$ & $\begin{array}{c}\text { Hasil } \\
\text { Model }\end{array}$ & Keterangan \\
\hline $\begin{array}{c}\chi 2-\text { Chi- } \\
\text { square }\end{array}$ & $\begin{array}{c}\text { Diharapka } \\
\text { n kecil }\end{array}$ & 2,853 & Baik \\
\hline $\begin{array}{c}\text { Sign.Pro } \\
\text { bability }\end{array}$ & $\geq 0.05$ & 0.00 & Baik \\
\hline GFI & $\geq 0.90$ & 0.986 & Baik \\
\hline AGFI & $\geq 0.90$ & 0.910 & Baik \\
\hline TLI & $\geq 0.95$ & 0.915 & Baik \\
\hline CFI & $\geq 0.95$ & 0.936 & Baik \\
\hline RMSEA & $\leq 0,08$ & 0.035 & Baik \\
\hline
\end{tabular}

Sumber : Ferdinand A, (2002)

Implementasi network systems di perusahaan dapat meningkatkan accessibility dan integration setiap perusahaan dalam memberikan pelayanan dan memenuhi business demands seluruh stakeholder. Hasil penelitian ini konsisten dengan penelitian yang dilakukan oleh Melville (2010) dan Broadbent and Weill (1997). Dengan perkembangan TI yang sangat pesat, perusahaan harus menggunakan TI yang mempunyai flexibility yang tinggi. Hal ini dapat diartikan bahwa SIC yang dimiliki oleh perusahaan harus dapat diakses oleh semua flatform baik itu hardware maupun software (Santhanam and Hartono, 2003).

Teknologi virtual sekarang ini sangat penting untuk keberlangsungan bisnis proses di perusahaan. Selain dapat meningkatkan effisiensi dan mengurangi biaya perawatan dalam perusahaan, virtual teknologi memiliki kemampuan untuk memanajemen SIC melalui automating computing (Gmach and Holcomb, 2004). Thin Client computing memiliki kemampuan memproses data yang lebih besar, hemat energy dan biaya perawatan yang murah (Pattinson and Cross, 2011). Teknologi cloud computing memiliki kemampuan yaitu sebagai internet-based computing centralizes di dalam pengolahan data dan serta memiliki kemampuan memberikan akses kepada stakeholder kapan dan dimana saja (Marston et al., 2011). Disamping itu juga perusahaan dapat memanfaatkan teknologi cloud computing sebagai disaster recovery bila terjadi bencana alam (Jadeja and Modi, 2012). Yang terakhir adalah teknologi RFID. Teknologi memiliki kemampuan dalam mengkontrol stok dalam perdagangan. Selain itu, teknologi RFID memiliki kemampuan untuk melacak posisi barang atau stok di gudang (Dukovska-Popovska et al., 2010).

\section{KESIMPULAN}

Dari hasil penelitian ini dapat disimpulkan bahwa:

- Bagi organisasi-organisasi di kota Palembang, dapat memanfaatkan hasil penelitian ini sebagai acuan maupun bahan evaluasi serta penyempurnaan dari kebijakan-kebijakan yang telah dan akan diambil, khususnya dalam hubungannya dengan layanan maupun masyarakat yang terlibat langsung maupun tidak langsung dengan pelayanan informasi.

- Berdasarkan data analisis dapat dikatakan bahwa perusahaan kota Palembang disarankan untuk memiliki infrastruktur TI yaitu Network Systems, interface multiplatforms, Database management systems, Virtual server, virtual database, Virtual Desktop, Thin Client computing, Cloud Computing, dan Radio Frequency Identifications. Jadi, dapat disimpulkan bahwa untuk mendukung bisnis proses dalam suatu perusahaan dibutuhkan suatu Infrastruktur TI seperti yang disebutkan diatas.

- Menjadi bahan studi lanjutan untuk mengembangkan SIC di perusahaan kota Palembang.

- Hasil penelitian ini juga diharapkan dapat digunakan sebagai informasi dan bahan pertimbangan, serta rekomendasi bagi para pembuat, pengambil dan pelaksana kebijakan 
pada perusahaan-perusahaan di kota Palembang.

- Tahapan selanjutnya yang akan dilakukan dalam penelitian ini adalah melanjutkan analisis data khususnya untuk melihat peranan sumber daya manusia (SDM) TI dan Manajemen TI. Hasil yang diharapkan setelah menganalisis konstruk SDM TI akan didapatkan kompetensi-kompetensi penting SDM TI yang akan mendukung keberlanjutan suatu perusahaan di kota Palembang, seperti, Kemampuan dibidang network computer, bahasa pemrograman, dan system operasi. Sedangkan dari Manajemen TI nanti, hasil analisis kontruk tersebut akan bermanfaat kompetensi apa yang harus dimiliki oleh perusahaan untuk suksesnya system infromasi mereka. Konstruk ini akan melihat sejauh mana peranan IT strategy, kebijakan dan hubungan dengan stakeholders dalam system informasi perusahaan kota Palembang.

- Ucapan terima kasih dan penghargaan yang sebesar-besarnya kepada Direktorat Riset dan Pengabdian Masyarakat Direktorat JenderalPenguatan Riset dan Pengembangan Kementerian Riset, Teknologi dan Pendidikan Tinggi atas program pendanaan penelitian ini.

\section{DAFTAR PUSTAKA}

|1|. BHARADWAJ, A. S. 2000. A ResourceBased Perspective on Information Technology Capability and Firm Performance: An Empirical Investigation. MIS Quarterly, 24, 169-196.

|2|. BOUdREAU, M. C., CHEN, A. \& HUBER, M. 2008. Green IS: Building sustainable business practices. Information Systems: A Global Text.

|3|. BOWEN, F. E., COUSINS, P. D., LAMMING, R. C. \& FARUKT, A. C. 2001. THE ROLE OF SUPPLY MANAGEMENT CAPABILITIES IN GREEN SUPPLY. Production and Operations Management, 10, 174-189.

|4|. BROADBENT, M. \& WEILL, P. 1997. Management by Maxim: How Business and IT Managers Can Create IT Infrastructures. MIT Sloan Management Review, 38, 77-7792.

|5|. DAO, V., LANGELlA, I. \& CARBO, J. 2011. From green to sustainability: Information Technology and an integrated sustainability framework. The Journal of Strategic Information Systems, 20, 63-79.

|6|. DUKOVSKA-POPOVSKA, I., LIM, M. K., STEGER-JENSEN, K. \& HVOLBY, H. H. RFID technology to support environmentally sustainable supply chain management. RFIDTechnology and Applications (RFID-TA),
2010 IEEE International Conference on, 1719 June 2010 2010. 291-295.

|7|. DUNCAN, N. B. 1995. Capturing flexibility of information technology infrastructure: A study of resource characteristics and their measure. Journal of Management Information Systems, 12, 37-37.

|8|. FERDINAND, A. 2002. Structural equation modeling dalam penelitian manajemen. Semarang: BP Undip.

|9|. GMACH, J. \& HOLCOMB, T. 2004. Server virtualization. Computer Technology Review, 2004/08//, p.37.

|10|. HAIR, J. F. 2010. Multivariate data analysis, Upper Saddle River, NJ, Prentice Hall.

|11|. JADEJA, Y. \& MODI, K. Cloud computingconcepts, architecture and challenges. Computing, Electronics and Electrical Technologies (ICCEET), 2012 International Conference on, 2012. IEEE, 877-880.

|12|. JIAO, H., CHANG, I. C. \& LU, Y. The relationship on information technology capability and performance: An empirical research in the context of China's Yangtze River delta region. 2008. IEEE, 872-876.

|13|. KAPLAN, D. 2009. Structural equation modelling: Foundations and extensions, Thousand Oaks, Sage Publications Inc.

|14|. KETTINGER, W. J., GROVER, V., GUHA, S. \& SEGARS, A. H. 1994. Strategic Information Systems Revisited: A Study in Sustainability and Performance. MIS Quarterly, 18, 31-58.

|15|. KLINE, R. B. 2010. Principles and Practice of Structural Equation Modeling, Third Edition, New York, New York : Guilford Publications.

|16|. KOVAR, J. F. 2008. Midmarket Storage And Disaster Recovery -- No Time To Lose -Make use of server virtualization to protect clients' environments. CRN, 32.

|17|. LEE, D. M. S., TRAUTH, E. M. \& FARWELL, D. 1995a. Critical skills and knowledge requirements of IS professionals: a joint academic/industry investigation. MIS Quarterly, 313-340.

|18|. LEE, D. M. S., TRAUTH, E. M. \& FARWELL, D. 1995b. Critical Skills and Knowledge Requirements of IS Professionals: A Joint Academic/Industry Investigation. MIS Quarterly, 19, 313-340.

|19|. MARSTON, S., LI, Z., BANDYOPADHYAY, S., ZHANG, J. \& GHALSASI, A. 2011. Cloud computingThe business perspective. Decision Support Systems, 51, 176-189.

|20|. MELVILLE, N. 2010. Information systems innovation for environmental sustainability. Management Information Systems Quarterly, 34, 1-21. 
|21|. MILLER, K. \& PEGAH, M. 2007. Virtualization: virtually at the desktop. Proceedings of the 35th annual ACM SIGUCCS fall conference. Orlando, Florida, USA: ACM.

|22|. MINGAY, S. 2007. Green IT: the new industry shock wave. Gartner RAS Core Research Note G, 153703, 2.

|23|. MINISTRY OF TELECOMMUNICATION AND INFORMATICS, I. 2011. Indikator TIK Indonesia 2011, Puslitbang Penyelenggaraan Pos dan Informatika Kementerian Komunikasi dan Informatika.

|24|. MOLLA, A. GITAM: A Model for the Adoption of Green IT. 19th Australasian Conference on Information Systems

|25|. 3-5 Desember 2008 Christchurch, New Zealand. 658-668.

|26|. MOLLA, A., PITTAYACHAWAN, S., CORBITT, B. \& DENG, H. 2011. An international comparison of green IT diffusion. International Journal of e-Business Management, 3, 1-23.

|27|. PATTINSON, C. \& CROSS, R. 2011. Does" thin client" mean" energy efficient"?

|28|. SANTHANAM, R. \& HARTONO, E. 2003. ISSUES IN LINKING INFORMATION TECHNOLOGY CAPABILITY TO FIRM PERFORMANCE. MIS Quarterly, 27, 125165.

|29|. SAYEED, L. \& GILL, S. An exploratory study on environmental sustainability and IT use. AMCIS 2008 Proceedings, 14-17 August 2008 Toronto, Canada.

|30|. SPESHOCK, C. 2010. Empowering Green Initiatives with IT: A Strategy and Implementation Guide, Wiley.

|31|. TABACHNICK, B. G. \& FIDELL, L. S. 2001. Using Multivariate Statistics, Allyn and Bacon.

|32|. TIPPINS, M. J. \& SOHI, R. S. 2003. IT competency and firm performance: is organizational learning a missing link? Strategic Management Journal, 24, 745-761.

|33|. WEILL, P. \& VITALE, M. 2002. What it infrastructure capabilities are needed to implement e-business models? MIS Quarterly, 1, 17-17.

|34|. XIAOXIA, D., HEPU, D. \& BRIAN, C. 2012. Evaluating the critical determinants for adopting e-market in Australian small-andmedium sized enterprises. Management Research Review, 35, 289-308.

|35|. ZHU, Q., SARKIS, J. \& GENG, Y. 2005. Green supply chain management in China: pressures, practices and performance. International Journal of Operations \& Production Management, 25, 449. 